\title{
Temporal Variation of Black Carbon Aerosol Concentration during Monsoon in Kathmandu Valley
}

\author{
Ram K. Sharma ${ }^{1}$, Binod K. Bhattarai ${ }^{1}$, Balkrishna Sapkota ${ }^{1}$, Mohan B. Gewali ${ }^{2}$, Berit Kjeldstad ${ }^{3}$ \\ ${ }^{1}$ Department of Engineering Science and Humanities, Institute of Engineering, Central Campus, Pulchowk, \\ Tribhuvan University, Nepal \\ ${ }^{2}$ Central Department of Chemistry, Tribhuvan University \\ ${ }^{3}$ Department of Physics, Norwegian University of Science and Technology \\ Corresponding email: rksharma2002@yahoo.com
}

\begin{abstract}
Black carbon aerosol was measured continuously for three months June, July and August 2009 at G block of Pulchowk Campus, Institute of Engineering, Department of Engineering Science and Humanities using Magee Scientific Aethalometer AE 31 model. The study period corresponds to monsoon season over Nepal. The study site Pulchow Campus is located at $27^{\circ} 22^{\prime} \mathrm{N}$ latitude and $85^{\circ} 32^{\prime} \mathrm{E}$ longitude. The diurnal variation of aerosol black carbon shows two peaks during morning and late evening. These two distinct peaks occur due to gradual increase in the anthropogenic activities and rush hour traffic. Among the three months of monsoon highest monthly average was observed during June while lowest during July and moderate on August with $5.3 \mu \mathrm{g} / \mathrm{m}^{3}, 3.0 \mu \mathrm{g} / \mathrm{m}^{3}$ and $3.8 \mu \mathrm{g} / \mathrm{m}^{3}$ respectively. The average rain fall in these months were $126 \mathrm{~mm}, 326.3 \mathrm{~mm}$ and $383 \mathrm{~mm}$ respectively. The concentration of aerosol black carbon is higher in dry month than rainy months because it is washed by rain once it is released in the atmosphere. In the daily average the highest value of aerosol black carbon was observed on $9^{\text {th }}$ June as $8.2 \mu \mathrm{g} / \mathrm{m}^{3}$ while lowest value on $16^{\text {th }}$ August as low as $1.9 \mu \mathrm{g} / \mathrm{m}^{3}$.
\end{abstract}

Keywords: aerosol, black carbon, Aethalometer, rainfall.

\section{Introduction}

Aerosols are tiny particles suspended in the atmosphere in the range of 0.01 to 10 microns. They can be solid such as smoke and dust, or liquid such as haze droplets. Aerosol black carbon mostly comes from the combustion of fossil fuels, biomass and coal, which are the main sources of energy for daily life. Dust, carbon monoxide, hydrocarbons, particulates make up the bulk of the aerosols [1]. Automobile tires, fire place smoke, barbecue grills, large scale agriculture (pesticide spraying), diesel engine, trains and aero plane also produce aerosols.

An incomplete combustion of fossil fuels or bio-fuel produces soot in the form of elemental or black carbon, and numerous organic carbon species. A black carbon aerosol absorbs solar radiation and is the second largest contributor to global warming, after green house gases [2]. Black Carbon may also have a regional climatic impact. The high concentration of soot over India and China is responsible for a trend toward increased flooding in the south and drought in the north [3]. It is estimated that the reduced atmospheric transparency caused by high soot concentrations decrease agricultural productivity by $10-20 \%$ [4]. The soot deposited on plant leaves also reduces plant productivity [5].

In general trend, it has been observed that concentration of aerosols (water soluble and water adhering) are decreased in rainy (Monsoon) season. How the concentration of black carbon 
aerosol changes in monsoon season which is insoluble in water and produced continuously by human activity and an important component of climate change is major concern of this study. More over how intensity and pattern of rainfall effects its concentration is another key point to observe in this study. It has been mentioned that sustainable development in the Asian monsoon countries depends on the monsoon [6]. Aerosols in the atmosphere can also effect the monsoon water by significantly altering the energy balance in the atmosphere and at the surface $[8,7]$.

Kathmandu Valley has bowl like structure covering an area of about 667sq.km.Itis located between $27^{\circ} 37^{\prime} 30^{\prime \prime} \mathrm{N}$ and $27^{\circ} 45^{\prime} \mathrm{N}$ latitude and $85^{\circ} 15^{\prime} \mathrm{E}$ and85 $22^{\prime} 30^{\prime \prime} \mathrm{E}$ longitude. The ancient city Kantipur was famous for temples and fertile land (Renamed as Kathmandu later). Due to rapid unplanned urbanization and fast migration of people from out side of the valley and neighboring countries for business has increased pollution. Due to this increasing population no of vehicles are increased in the valley for transportation. As a consequence the use of fuels has increased remarkably which is the main source of black carbon aerosol. In this context it is very urgent to know the actual scenario of black carbon aerosol concentration in Kathmandu valley in order to observe the possible impacts of it in the climate change at present and in the future. So, present work is very relevant to access black carbon aerosol concentration and its pattern in the Kathmandu valley. From the existing literature it is the first of its kind to observe ground level black carbon aerosol concentration in this area. More over this work will also try to attempt to analyze the variation of black carbon aerosols on the basis of available meteorological information.

\section{Methodology}

An Aethalometer manufactured by Magee Scientific AE31 model was deployed at second floor of Engineering Science and Humanities building, Pulchowk Campus to monitor concentration of aerosol black carbon. This instrument comprises of seven channels from $370 \mathrm{~nm}, 470 \mathrm{~nm}, 520 \mathrm{~nm}$, $590 \mathrm{~nm}, 660 \mathrm{~nm}, 880 \mathrm{~nm}$ and $950 \mathrm{~nm}$ respectively. Among these wave lengths this work is focused on $370 \mathrm{~nm}$ and $880 \mathrm{~nm}$ because they measure elemental carbon and black carbon concentration and are the forms of carbon aerosols. The Aethalometer is an instrument that provides a real time read out of the concentration of black carbon aerosol particles in the air stream. The instrument aspirates ambient air using its inlet tube and black carbon mass concentration is estimated by measuring the change in the transmittance of a quartz filter tape, in which the particles are deposited. The instrument was kept operating at a time interval of 5 minutes, round the clock with a flow rate of 2 liter per minute (2LMP).

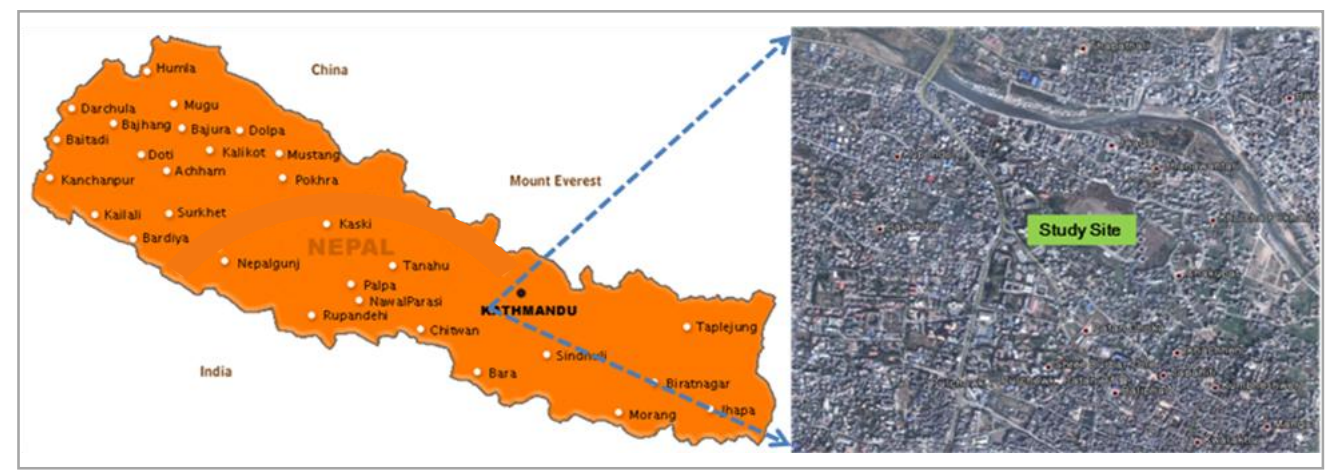

Figure 1: Study site Pulchowk Campus in the map of Nepal. 
Pulchowk Campus is located at $27^{\circ} 22^{\prime}$ latitude and $85^{\circ} 32^{\prime}$ longitude in Lalitpur sub-metropolitan city. This is a densely populated urban area of the Lalitpur district.

\section{Result and Discussion}

The concentration of aerosol black carbon was regularly measured in the month of June, July and August 2009. From the data analysis it has been observed that the concentration of black carbon is comparatively higher in the month of June while it is lowest in the month of July. The average daily value shows the highest value of black carbon on 9th June 2009 as $8.2 \mu \mathrm{g} / \mathrm{m}^{3}$ while the lowest value on $16^{\text {th }}$ August 2009 as $1.9 \mu \mathrm{g} / \mathrm{m}^{3}$.

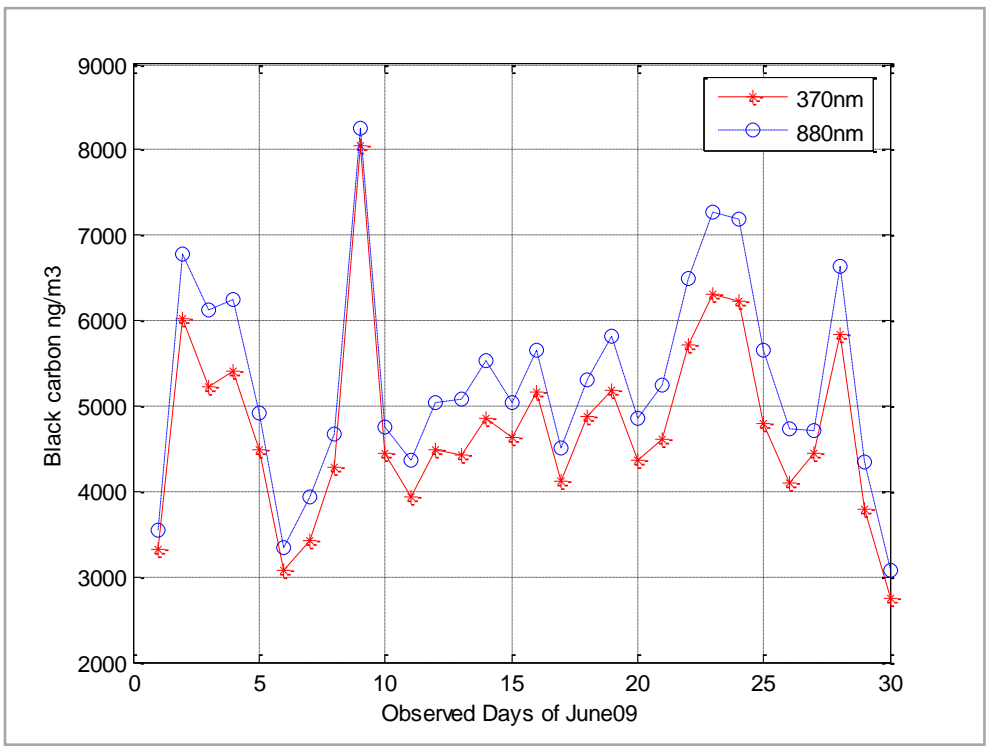

Figure 2: Average Concentration of black carbon for the month of June2009 in Kathmandu

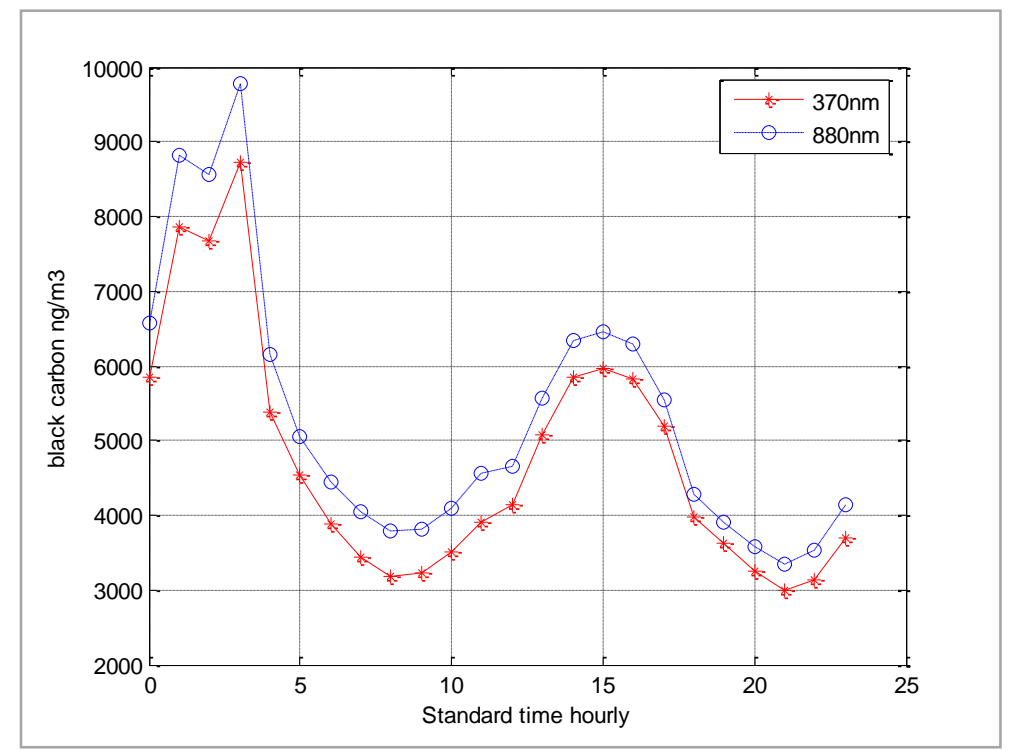

Figure 3: Diurnal variation of aerosol black carbon on the month of June 2009 
In the month of June the concentration of black carbon recorded was comparatively higher among the three observed months. The maximum value of black carbon was $8.2 \mu \mathrm{g} / \mathrm{m}^{3}$ on $9^{\text {th }}$ June while the lowest value recorded was $3.0 \mu \mathrm{g} / \mathrm{m}^{3}$ on $30^{\text {th }}$ June and is shown in figure 2 .

There is a distinct diurnal variation of black carbon aerosol; two distinct picks are observed one in the morning and another in the late evening. Figure 2 reflects two typical picks due to anthropogenic emission of black carbon around 9O'clock morning (AM) and around 90'clock (PM) late evening local time. This is mainly due to high traffic density and general activity of the peoples of the valley around the observed time. It should be noted here that Kathmandu time is 5:45 ahead of UT.

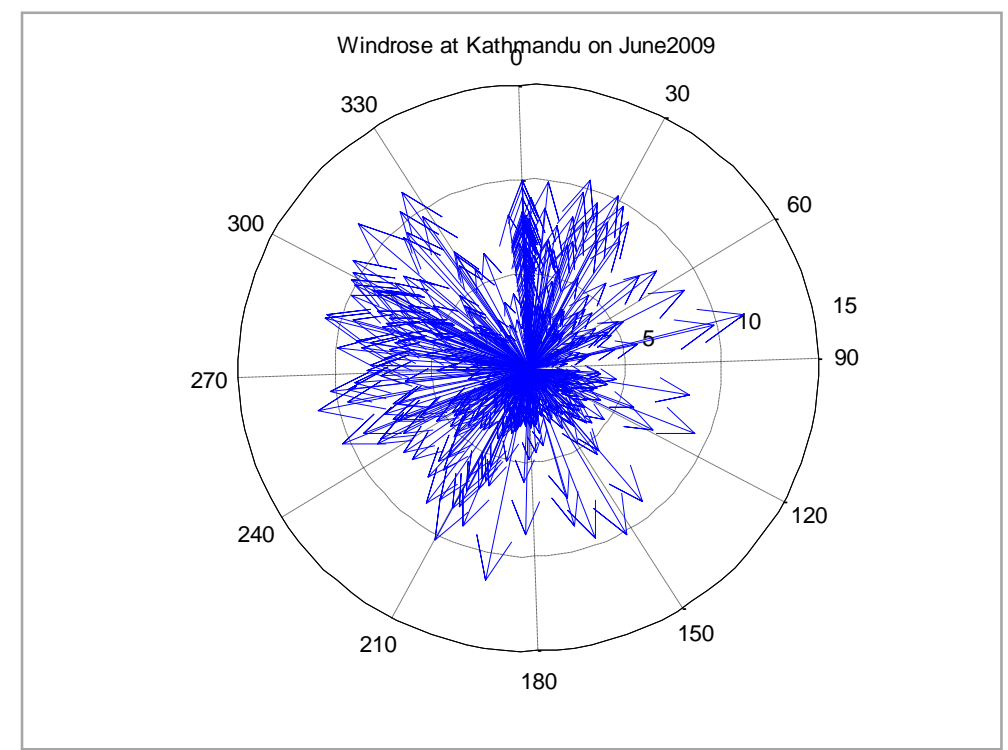

Figure 4: Wind rose for June 2009 representing wind speed and wind direction

Wind rose of June clearly shows domination of west south west, west, west north west, north west and north north east wind with about $10 \mathrm{~km} / \mathrm{h}$ speed. This wind speed and its pattern is unable to reduce the existing amount of black carbon aerosol from the atmosphere because it is not the favorable one.

In the month of July the highest value of black carbon recorded was $4.6 \mu \mathrm{g} / \mathrm{m}^{3}$ on $31^{\text {st }}$ July while the lowest was $2.1 \mu \mathrm{g} / \mathrm{m}^{3}$ on $8^{\text {th }}$ July. There is no any typical monthly trend of black carbon aerosols in monsoon season. 


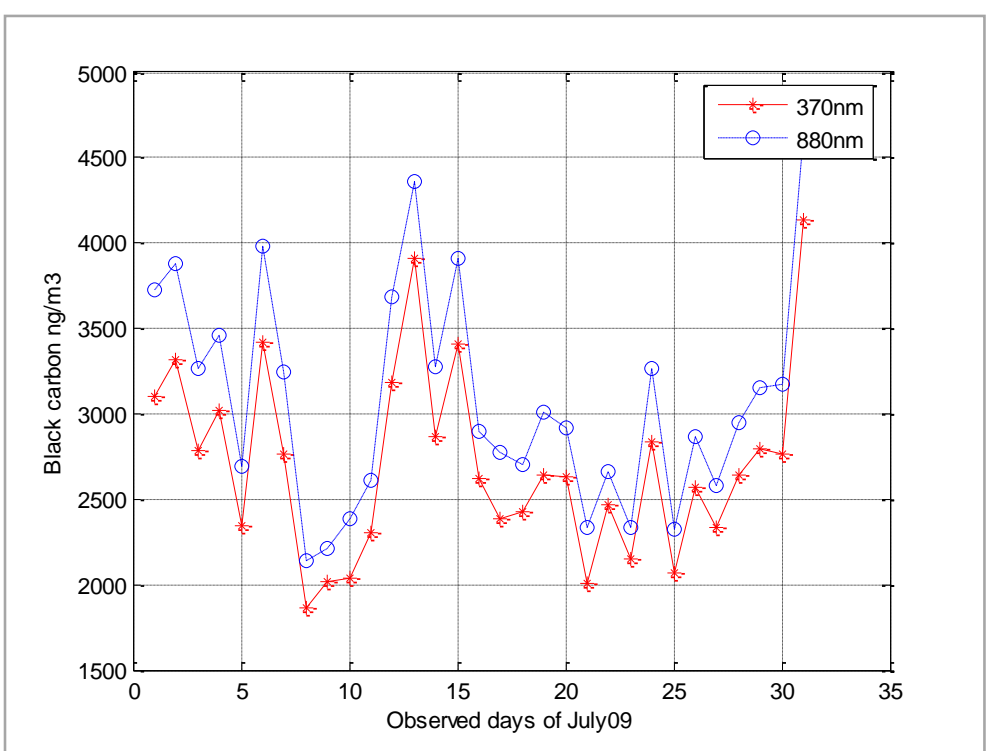

Figure 5: Concentration variation of black carbon during July2009

Diurnal variation of black carbon is also observed in the month of July. Two distinct picks are clearly visualized (figure 5) one at morning about 9 O'clock and another about 8 O'clock night time. This trend is supportive for the anthropogenic emission of black carbon in the valley as explained earlier.

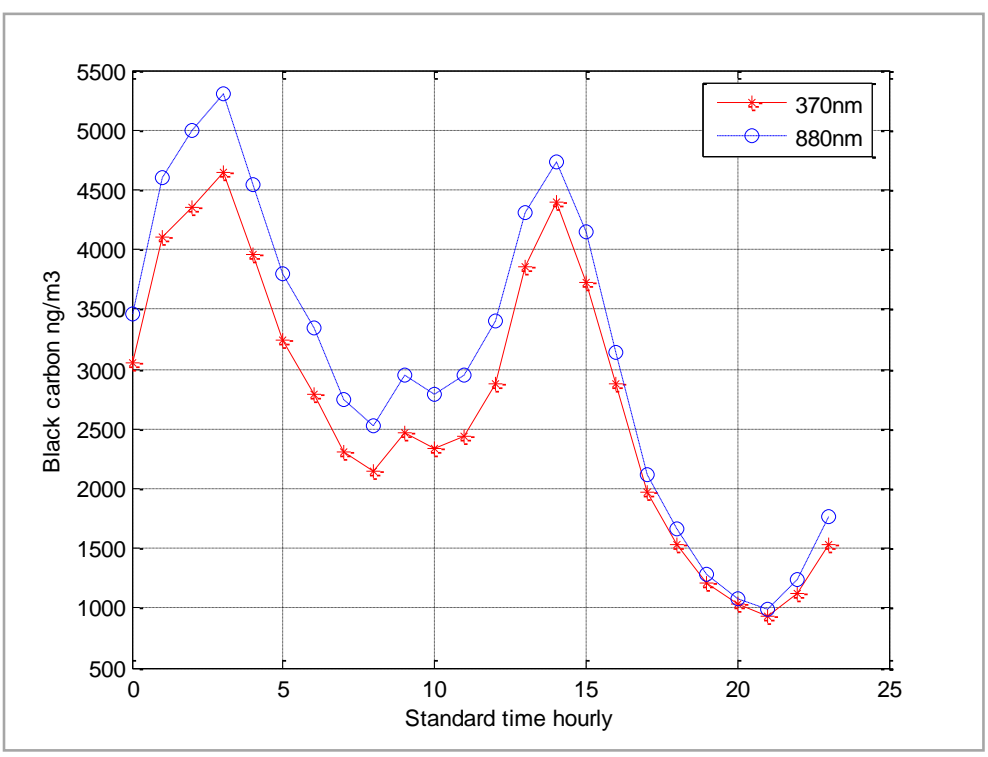

Figure 6: Diurnal variation of black carbon in the month of July2009 


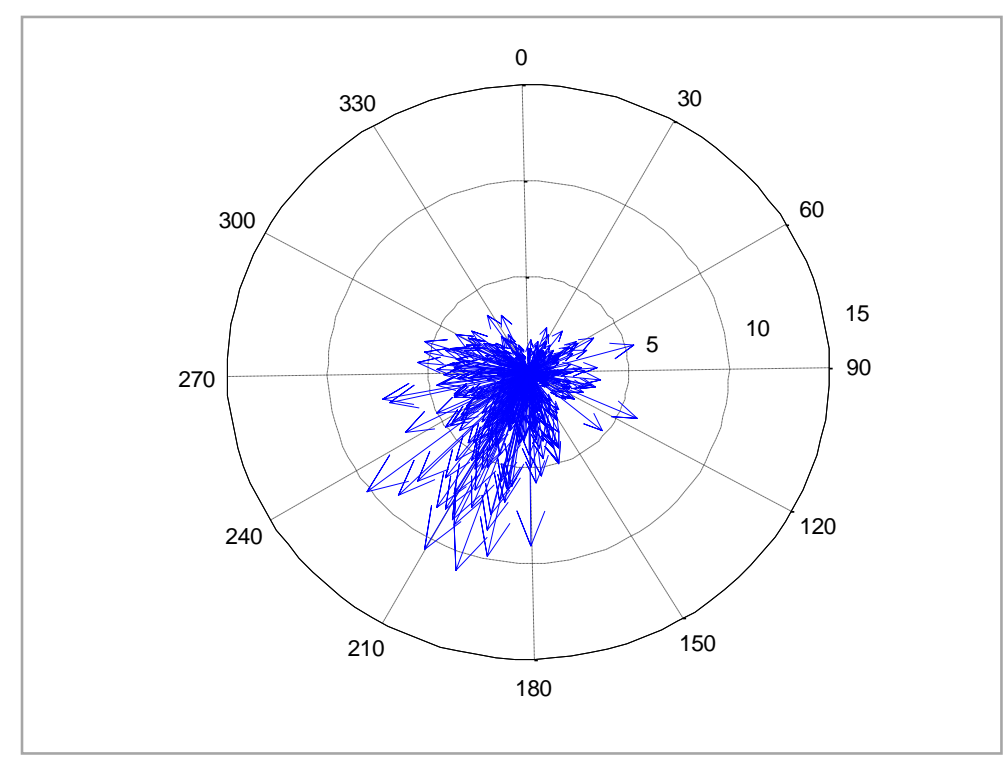

Figure 7: Wind rose for July 2009 showing wind speed and wind direction

Wind rose of July clearly reflects the domination of high speed winds from south south west and south west in the range of more than $10 \mathrm{~km} / \mathrm{h}$ while in the rest of area below $5 \mathrm{~km} / \mathrm{h}$ so not playing significant role in the flushing.

In the month of August the trend of black carbon concentration was in between July and June. The highest value recorded was $5.2 \mu \mathrm{g} / \mathrm{m}^{3}$ on $4^{\text {th }}$ August and the lowest value $1.9 \mu \mathrm{g} / \mathrm{m} 3$ on $16^{\text {th }}$ August

The monthly average of aerosol black carbon obtained was $5.3 \mu \mathrm{g} / \mathrm{m}^{3}, 3.0 \mu \mathrm{g} / \mathrm{m}^{3}$ and $3.2 \mu \mathrm{g} / \mathrm{m}^{3}$ in June, July and August respectively.

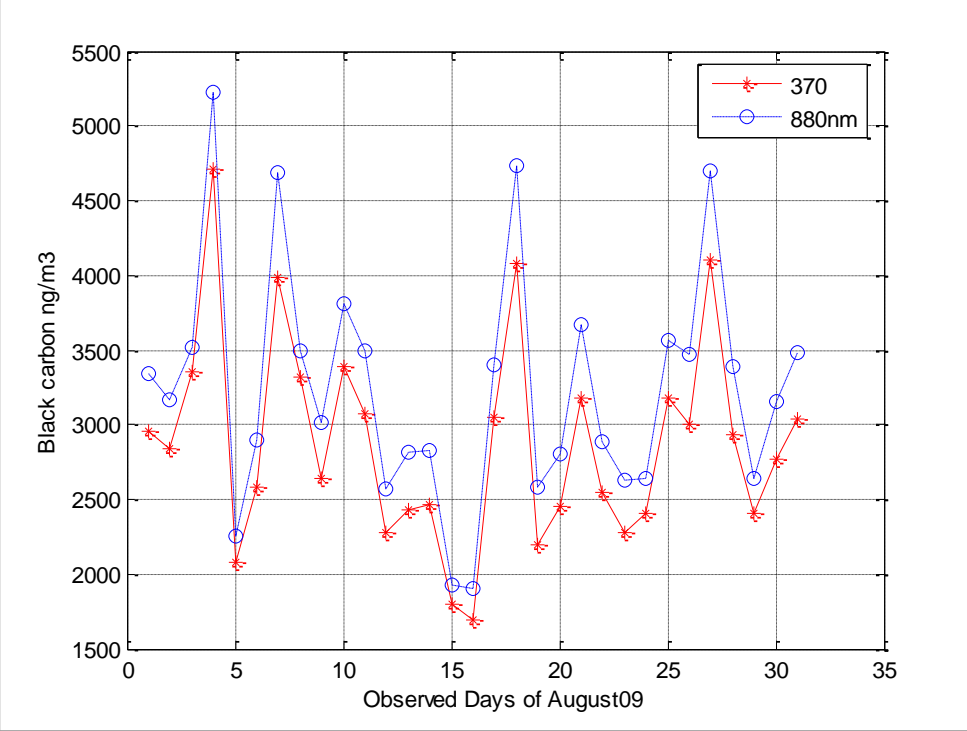

Figure 8: Concentration variation of black carbon in the month of August 


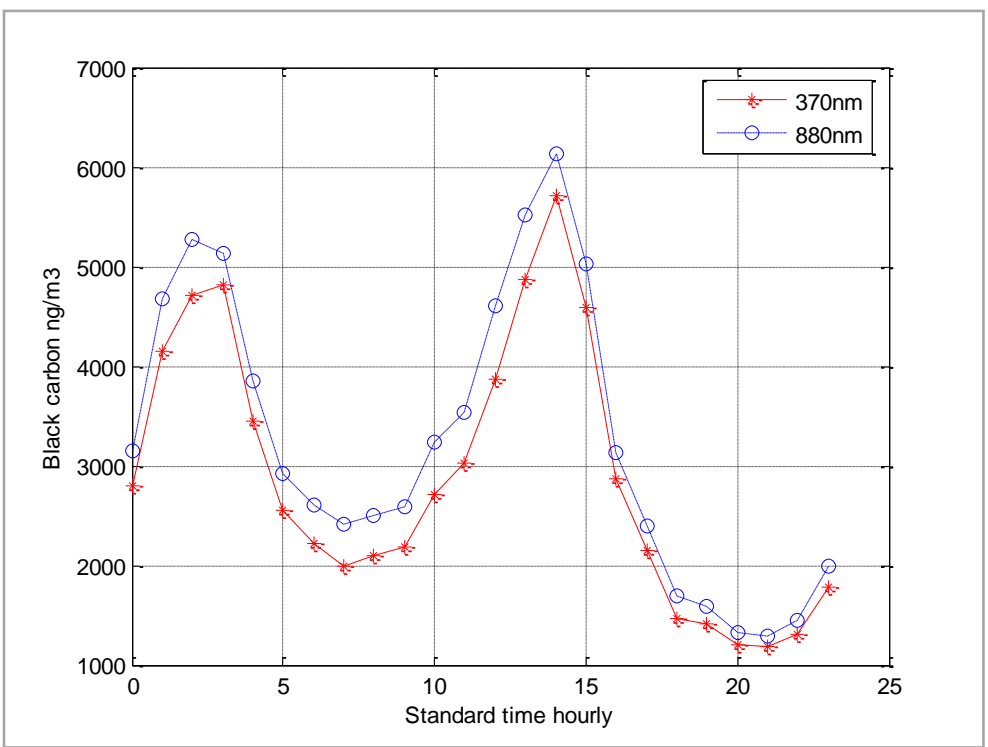

Figure 9: Diurnal variation of black carbon in the month of August 2009

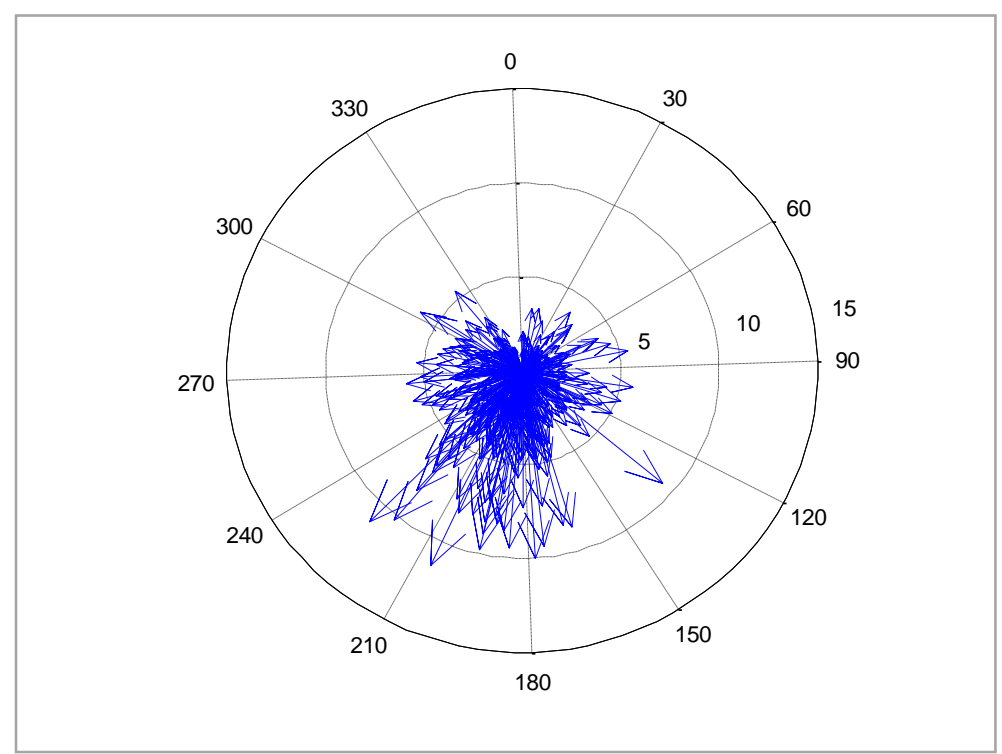

Figure 10: Wind rose for August 2009 representing wind speed and wind direction

Wind rose of the month of August also shows domination of high speed wind from south, south south west and south west in the range of $10 \mathrm{~km} / \mathrm{h}$. This trend and speed of wind is unable to flush existing black carbon aerosol from the atmosphere because the experimentally observed trend of west to east wind speed is only responsible for reduction.

As mentioned earlier the concentration of aerosol black carbon among the three observed months of June, July and August minimum value is observed on July while the highest value on June. Irrespective to rain fall pattern black carbon aerosol concentration in August is more than July. According to Nepal Hydrology and Metrology data maximum rain fall is recorded on August but rain fall days are more in July as a result of which black carbon aerosol is 
comparatively less in this month. Figure 10 has shown the pattern of aerosol black carbon in the months of monsoon season.

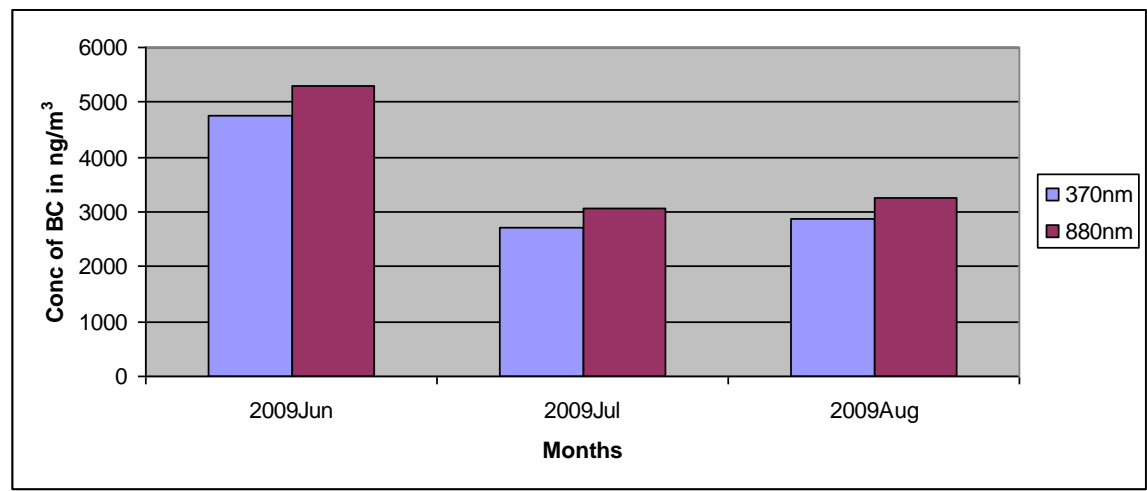

Figure 11: Trend of black carbon concentration in Monsoon season 2009.

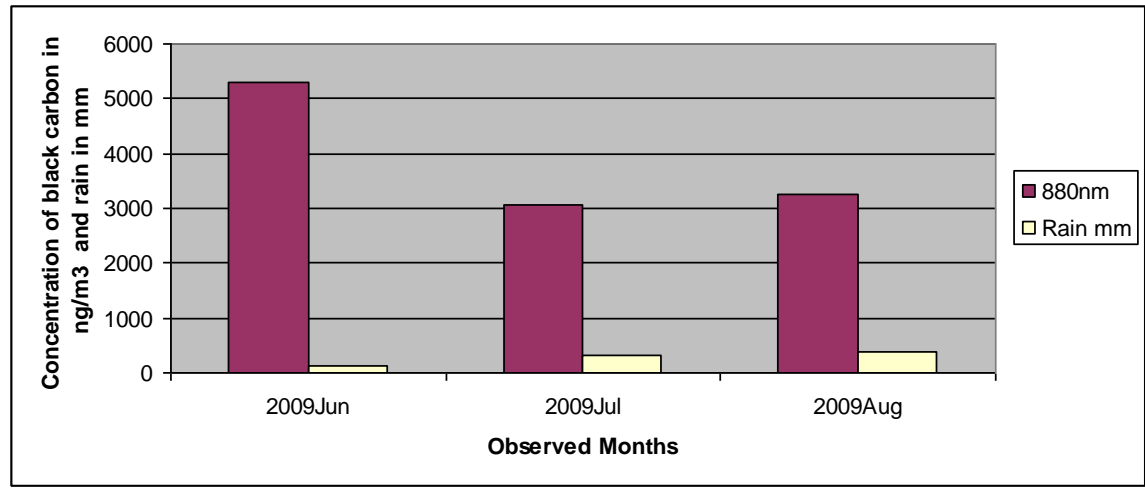

Figure 12: Black carbon and rain pattern in Monsoon season 2009

\section{Conclusion}

Data of black carbon aerosol is shown and analyzed. Distinct diurnal variation of black carbon aerosol is observed in all the observed months of monsoon season of the Kathmandu valley. Aerosol black carbon emission is due to anthropogenic process and vehicular emission plays a significant part in the total concentration of it.

Concentration of aerosol black carbon is comparatively higher in June among the three months of monsoon. This way is attributed to low average rain fall than the other two months.

Aerosol black carbon concentration is not reduced to that extent as other water soluble aerosols in rainy days because of its water insoluble nature and regular emission in all the times in similar pattern. In addition it has also been concluded that not only rain fall but also its pattern (no of rain fall days) influences in the variation of black carbon. Wind speed and its pattern in the monsoon season is not typically westerly and south westerly which is responsible for the flushing of Kathmandu valley aerosol so, not playing any significant role in the reduction of black carbon aerosol. 


\section{Acknowledgements}

This work is supported by Solar Radiation and Aerosol Project in Himalayan Region (SAHR) by providing instrument for regular monitoring of aerosol black carbon and other essential accessories for the analysis. Ram Kumar Sharma also acknowledges for the financial support for the study to SAHR.

\section{References}

[1] Salby, M. (1996). Fundamentals of Atmospheric Physics, Academic Press, California.

[2] Jacobson, M. Z. (2002). Control of fossil fuel particulate black carbon and organic matter, possibility the most effective method of slowing global warming, Journal of Geophysical Research, 107 (D19), 4410-?.

[3] Menon, S., Hansen, J. E., Nazarenko, L., and Luo, Y. (2002). Climate effects of black carbon aerosols in China and India, Science, 297, 2250-2253.

[4] Chameides, W.L., Yu, H., Liu, S. C., Bergin, M., Zhou, X., Mearns, L., Wang. G., Kiung, C. S., Saylar, R. D., Luo, C., Huang, Y., Steiner, A., and Giorgi, F. (1999). Case study of the effects of atmospheric aerosols and regional haze in agriculture: an opportunity to enhance crop yields in China through emission controls, Proceedings of the National Academy of Science, 96, 13626-13633.

[5] Bergin, M., Greenwald, R., Xu, J., Berta, Y., and Chemeides, W. L. (2001). Influence of aerosol dry deposition on photosynthetically active radiation available to plants: a case study in the Yangtze delta region of China, Geophysical Research Letters, 28(18), 3605-3608.

[6] Lua, K.M., Ramanathan, K., Wu, G. X., Li, Z., Tsay, S. C., Hsu, C., Sikka, R., Holben, B., Lu, D., Tartari, G., Chin, M., Koudelova, P., Chen, H., Ma,Y., Huang, J., Taniguchi, K., and Zhang, R. (2008).The Joint Aerosol Monsoon Experiment -A New Challenge for Monsoon Climate Research. Bulletin of American Meteorological Society, 89, 369-383.

[7] Li, W. F., Bai, Z. P., Liu, A. X., Chen, J. and Chen, L. (2009). Characteristics of Major PM 2.5 Components during winter in Tianjin, China, Aerosol Air quality Research, 9, 105-119.

[8] Ramanathan, V., Crutzen, P. J., Kiehl, J. T., and Rosenfeld, D. (2001). Atmosphere -Aerosols, Climate, and the Hydrological Cycle, Science, 294, 2119-2124.

[9] Li, Z. (2004). In Observations, Theory, and Modelling of the Atmospheric Variability, Zhu, X. (Eds.), Aerosol and Climate: A Perspective from East Asia, World Scientific Publication, Company, 501-525. 